\title{
SUPPORTING GENDER EQUITY \\ THROUGH FOOD SYSTEM BUSINESSES IN LOWER-INCOME COUNTRIES
}



GAIN Working Paper $\mathrm{n}^{\circ} 11$

October, 2020

Stella Nordhagen 


\section{ABOUT GAIN}

The Global Alliance for Improved Nutrition (GAIN) is a Swiss-based foundation launched at the UN in 2002 to tackle the human suffering caused by malnutrition. Working with governments, businesses and civil society, we aim to transform food systems so that they deliver more nutritious food for all people, especially the most vulnerable.

\section{Recommended citation}

Nordhagen S. Supporting Gender Equity through Food System Businesses in Lower-Income Countries. Global Alliance for Improved Nutrition (GAIN). Working Paper \#11. Geneva, Switzerland, 2020. DOI: https://doi.org/10.36072/wp.11

\section{(C) The Global Alliance for Improved Nutrition (GAIN)}

This work is available under the Creative Commons Attribution-Non-Commercial-Share Alike 4.0 IGO licence (CC BY-NC-SA 4.0 IGO; https://creativecommons.org/licenses/by-nc-sa/4.0/). Under the terms of this licence, you may copy, redistribute, and adapt the work for non-commercial purposes, provided the work is appropriately cited, as indicated below. In any use of this work, there should be no suggestion that GAIN endorses any specific organisation, products or services. The use of the GAIN logo is not permitted. If you adapt the work, then you must license your work under the same or equivalent Creative Commons license. The contributions of third parties do not necessarily represent the view or opinion of GAIN.

\section{Acknowledgements}

Thanks to Teale Yalch and Abigail Pelon for providing information and input related to GAIN's Marketplace for Nutritious Foods programme, and to Saul Morris and Lynnette Neufeld for helpful comments on an earlier version of this paper. All photographs included in this document have been taken with consent for use in publications.

\section{GAIN WORKING PAPER SERIES}

The GAIN Working Paper Series provides informative updates on programme approaches, research and evaluations, and on topics of relevance for our work.

The Global Alliance for Improved Nutrition (GAIN)

Rue de Varembé 7

1202 Geneva

Switzerland

T: +41227491850

E: info@gainhealth.org 


\section{SUMMARY}

Supporting small enterprises in the food system is central to improving access to safe and nutritious foods in low- and middle-income countries (LMICs)-and therefore to improving nutrition. However, the ways in which such enterprises are supported can have important implications for achieving other social goals, such as gender equity and women's empowerment. Despite this, gender issues are often not considered when designing programmes and policies to develop food system enterprises. this paper reviews the literature on women business owners and entrepreneurs, with a focus on those in the food system and in LMICs, and uses the findings to develop recommendations for making such programmes more supportive of gender equity. Our review uncovered 90 relevant publications, 53 of which focused on LMICs (primarily in Africa). These show clearly that while both men and women face barriers to entrepreneurship and business ownership, those faced by women are generally higher. Women face limitations on mobility, lack of access to finance, lack of access to business networks and mentors, limited leadership experience, lower literacy and numeracy, discriminatory gender norms and stereotypes, inadequate premises, and higher risk of harassment or bribery by officials as well as a dual burden of work stemming from home-based care responsibilities. However, women entrepreneurs also face opportunities, and there are many examples of successful female entrepreneurs. As women are over-represented in the agri-food sector compared to other sectors, supporting food system enterprises offers a particularly important opportunity to support genderequitable economic growth as well as improved nutrition.

\section{KEY MESSAGES}

- Women's participation in entrepreneurship varies across settings but is generally lower than for men. Women are more likely to start enterprises within the food sector than in other sectors but commonly face larger barriers to formalising businesses (especially with regards to compliance and certification), posing a barrier to growth.

- Both men and women face barriers to business ownership, but those faced by women are generally higher. These include poor access to finance, networks, and mentors; low literacy and numeracy; limited business skills; gender norms; and limited mobility due to cultural norms and safety concerns.

- Women's dual burdens of professional and home-based work often places limits on the amount of time and energy they can devote to a business.

- Negative stereotypes about women-owned businesses can be self-fulfilling; it is thus essential to recognise and accommodate the unique challenges that women entrepreneurs face without reinforcing such stereotypes.

- Developing gender-transformative approaches will require work with both men and women to address biases or stereotypes around women in business, gender roles and division of labour within and outside the home, and how men and women interact. 


\section{BACKGROUND AND OBJECTIVE}

Proper nutrition is a central component of improving health, development, productivity, and wellbeing, and key to achieving the Sustainable Development Goals (1). However, about 70\% of children in sub-Saharan Africa and South Asia do not consume a diet of minimum adequate diversity and about $30 \%$ of them are stunted (too short for their age, a sign of chronic malnutrition); about $30 \%$ of adolescents in these regions do not eat vegetables even once a day, and a similar share of adults are overweight or obese (2).

Central to addressing these issues in low- and middle-income countries (LMICs) is ensuring that local consumers have access to safe, nutritious foods at affordable price points and in desirable forms. This depends in part on the private sector. Even poor household in rural areas obtain large shares of their food from purchases, with over $50 \%$ of food consumed (by value) coming from purchases in most LMICs $(3,4)$. These purchased foods make important contributions to dietary diversity $(5,6)$. Within the private sector, micro-, small-, and mediumsized enterprises (MSMEs) play critical roles in LMIC food systems $(7,8)$, from production through storage, distribution, and processing sectors to wholesale and retail. ${ }^{1}$ For example, an estimated $72-83 \%$ of food consumed in India is handled by MSMEs (10) and traditional food supply chains dominate $50-80 \%$ of food economies in LMICs in Asia and Africa (11). MSMEs are also important sources of employment, estimated to be responsible for $2 / 3$ of global jobs and most new job creation (70\% in emerging markets) (12). They are crucial for creating markets for farmers and predicted to play a key role in LMIC food systems over the next 10-20 years (13).

Supporting MSMEs in LMIC food systems to produce more (and better) safe and nutritious foods is thus central to improving accessibility of such foods and supporting improved nutrition. Further, support to MSMEs in LMIC food systems offers a way to further other social goals beyond nutrition-including increased high-quality employment, economic growth, women's empowerment, and gender equity. These last two points, however, are often underemphasized in discussions and interventions that see MSMEs as neutral, impersonal entitiesas opposed to being made up of people and shaped by social norms, roles, and practices. Understanding the gender gaps related to food system MSMEs can help ensure interventions increase gender equity-while also supporting improved population nutrition. In addition, all MSMEs are not created equal: their capacities, goals, and needs vary widely, and one potential determinant of this variance is the gender of the firm owner or leaders. By better understanding the challenges and opportunities faced by women-owned firms, one can adapt programmes and policies that support MSMEs in LMIC food systems to better meet their needs.

As such, this paper reviews prior research on gender and MSMEs in LMICs, with an emphasis on food system companies where feasible. Because most research does not distinguish

\footnotetext{
${ }^{1}$ Different countries and agencies use different definitions (usually based on number of employees or annual turnover) for 'micro, small, and medium-sized enterprises' based on their national context; the threshold for 'large' tends to be higher in high-income countries than lower-income countries. In South Africa, for example, a micro-business has five or fewer employees and a turnover up to about 6,000 USD, a very small or small business has 6-50 employees, and a medium-sized business employs up to 100 in agriculture and 200 in other sectors. In Bangladesh, a small business has 16-50 employees; in Nigeria, an SME must have about 13,000 - 1,300,000 USD in assets and a staff of 11-100 employees (9).
} 
among micro, small, and medium-sized firms, this paper examines them jointly while acknowledging that the constraints and opportunities faced will differ widely between a fledgling micro-enterprise and a growing medium-sized firm. The focus of the analysis is on women as entrepreneurs, firm leaders, and managers, as opposed to women as workers or in supply chains (a topic that will be covered in a future paper). While the focus is on genderrelated issues, gender is but one component of identity and other non-gender factors (e.g., age, race, ethnicity, education) also shape the challenges and opportunities faced by MSME leaders, though they are not covered here.

The next section discusses the methods used in the review that informs this paper, while the subsequent sections outline main results, first considering the landscape of MSMEs and food system MSMEs and their performance, then discussing barriers to women's entrepreneurship and access to supporting business development services. The last sections discuss some of the caveats of the analysis, before concluding by offering some recommendations for programmes that aim to support food system MSMEs.

\section{METHODS}

This scoping review did not aim to be comprehensive and uncover or summarise the entire scope of work done related to women in business and entrepreneurship in LMICs. Rather, the aim was to identify the main themes emerging from that work. As such, a scoping review approach was used (14). Scoping reviews are a tool for identifying and mapping the available evidence on a topic (15). They provide a rigorous method for mapping existing areas of research, identifying gaps in the evidence, and summarizing research results, using transparent and replicable methods (16). They do not aim to be fully comprehensive, identify all studies on a given topic, or provide a clear answer to a particular question or a definitive judgement of the effectiveness of different interventions (15). Scoping reviews typically have a broader scope than traditional systematic reviews and allow the researcher to consider a greater range of study types and methodologies, across disciplines, than is typically feasible via a systematic review. The method is thus appropriate for the topic examined here.

Two search methods were used to identify relevant work. First, literature was retrieved from Google Scholar, published in 2000 or later, using a series of keyword searches in March May 2020. ${ }^{2}$ The first 100 results of each search (ranked by relevance to the search terms) were reviewed by title for apparent relevance; relevant abstracts were then screened for inclusion. Second, searches of the websites of relevant international organisations (International Labour Organisation, UN Women, International Finance Corporation, World Bank, International Centre for Research on Women, and International Food Policy Research Institute) were carried out. All types of studies were eligible for inclusion, with no date limitations. The focus was placed on studies on LMICs, though some insights are also drawn from the literature on high-income countries.

\footnotetext{
${ }^{2}$ The search terms used were: (women or female) AND business; (women or female) AND business AND (Africa or Asia); (women or female) AND entrepreneur; (women or female) AND entrepreneur) AND (Africa or Asia); Gender AND business AND (Africa or Asia).
} 
Overall, the review draws on 85 publications, 53 of which are specifically focused on LMICs. Of those in LMICs, $15 \%$ focused on LMICs in general or looked at multiple regions; $47 \%$ focused on countries in Africa, $26 \%$ on Asia, $6 \%$ on Middle East and North Africa, and 6\% on other countries. Of the included publications, $59 \%$ were published in the past 10 years. Most publications were either peer-reviewed journal articles $(36,40 \%)$ or reports of UN organisations $(36,40 \%) ; 12$ (13\%) were reports from other organisations, and two were working papers from universities or research institutes.

\section{WOMEN IN BUSINESS}

The level of women's participation in entrepreneurship varies widely across settings but is generally lower than for men (17); in high-income Group of Seven (G7) countries, men are twice as likely as women to be entrepreneurially active (18). Data from LMICs are scant: the amount of data available on MSMEs is limited, and that which exists is often not genderdisaggregated and may leave out the informal sector $(19,20)$. Moreover, women-owned businesses are more likely to be smaller and in sectors that are under-counted (20). However, it is generally thought that men outnumber women among entrepreneurs in most LMICs (21), with an estimate of 31-38\% of formal SMEs in emerging markets being owned by women (22). In India, for example, only 10-13\% of firms are owned by women (23), with similar numbers cited for Indonesia (24) and Bangladesh (25). At the regional level, the Middle East and North Africa has the lowest levels of women-owned firms, at 12-15\% (26). There are, however, some settings in which women entrepreneurs outnumber men-such as South Africa, Cambodia, and Thailand $(27,28)$. Figure 1 shows regional averages for the share of businesses (small, medium, or large) with a woman among the principal owners; the overall global average is $34 \%$, ranging from a low of $18 \%$ in South Asia to a high of $50 \%$ in Latin America and the Caribbean.

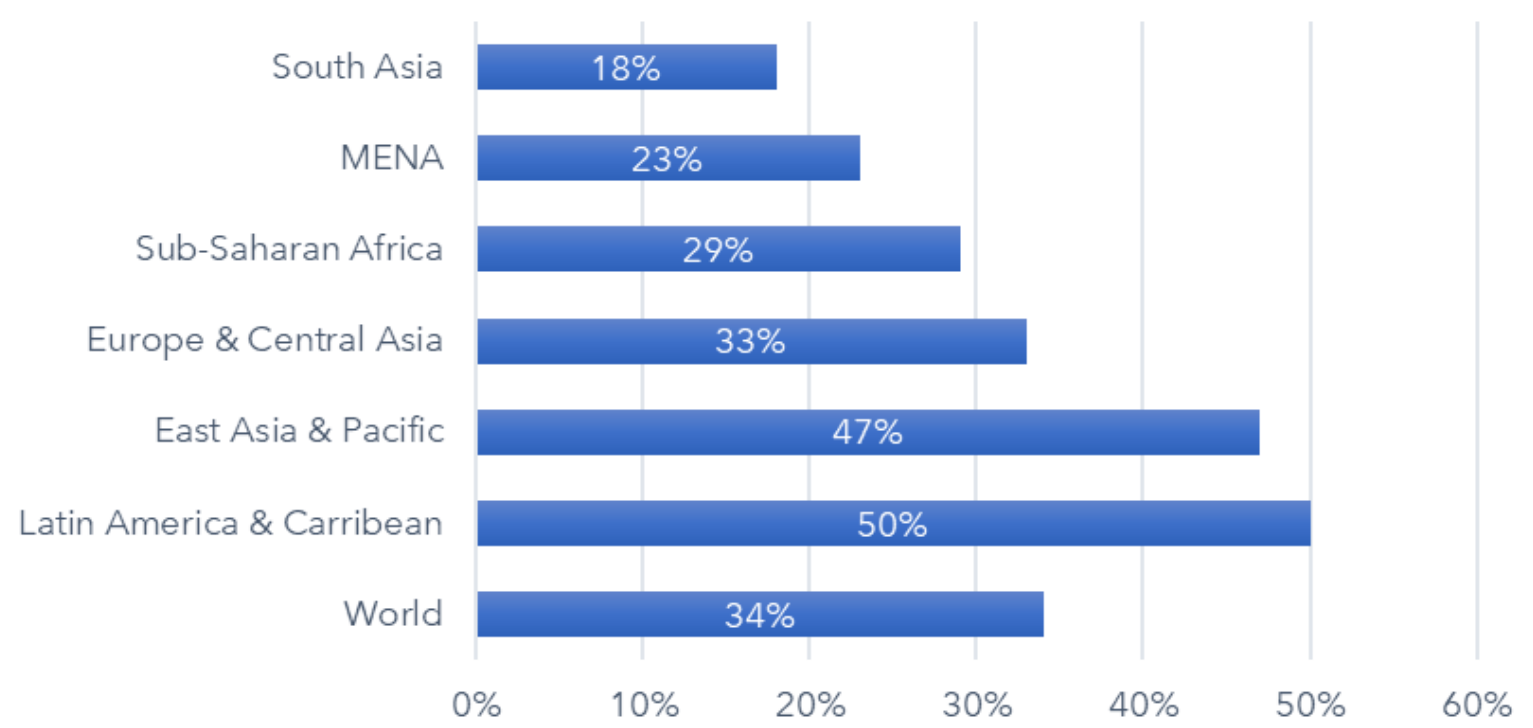

Share of businesses with a women among the principal owners (\%)

Figure 1. Share of businesses with a women owner, by region.

Notes: Refers to small, medium, and large firms; data circa 2018. Source: World Bank Gender Data Portal. 


\section{WOMEN ENTREPRENEURS IN THE FOOD SECTOR 3}

Compared to other sectors, women tend to be over-represented in the agri-food sector, largely due to its overlap with stereotypes about women's roles (i.e., as a preparer and provider of food) (20). In West Africa, for example, the food system accounts for $68 \%$ of employed women, who make up $83 \%$ and $72 \%$ of those employed in food processing and food marketing, respectively (31). Women-owned firms were found to be similarly concentrated in the food sector in Java (32). This varies somewhat by setting, however. In Bangladesh, for example, women are concentrated in garment production first, with food manufacturing being the second-most popular sector for women (25); in India, women were found to be most concentrated in tobacco products, paper products, apparel and textiles, with the food industry being only $11 \%$ women (33). In the Caribbean, women were found to be concentrated in the food sector in Trinidad and Tobago but not Suriname and Barbados (34). Aside from owning small businesses, women are also commonly self-employed food sector workers, particularly in the informal retail sector, such as street food sellers (e.g., much of Kenya's fruit and vegetables are sold by 'mama mbogas', or vegetable women, and about $80-90 \%$ of street food sellers in Nigeria are women $(35,36))$. Overall, women entrepreneurs are central actors in many local food systems. Box 1 offers examples of three successful women-run food businesses in Africa.

\footnotetext{
${ }^{3}$ There is a large literature on women's role in subsistence and smallholder farming. In short, women make up a large share of the agricultural labour force (close to $50 \%$ in many countries, (29)) but often have lower access to inputs, information, training, capital, and credit (30). As most of these farming operations are seen as subsistence oriented and thus not 'businesses', this section focuses primarily on larger-scale food and agriculture SMEs, including producers but also those in wholesaling, cold chain services, transport and storage, processing, packaging, and retail.
} 


\section{BOX 1. EXAMPLES OF WOMEN-RUN FOOD SYSTEM ENTERPRISES}

Successful women-owned businesses can be found throughout the food system in any country. Examples of these include:

Kwanza Tukule is a Kenyan firm that sells precooked beans to local street food vendors, who in turn serve them, ready-to-eat, to low- and middle-income consumers, such as laborers in Nairobi's busy central areas. Beans are an affordable source of protein and other nutrients. Unfortunately, high-quality beans can be hard to source in Kenya and take hours to cook, requiring a significant amount of cooking fuel for street food vendors-who often already face thin margins. Kwanza Tukule has solved this dilemma by making it easy and inexpensive for vendors to purchase and pay for high-quality, precooked beans through a smartphone app. As a result, Kwanza Tukule has reduced the time, energy, and cost of cooking beans for vendors while also improving the quality and safety of the beans sold. They can now produce and distribute enough precooked beans to feed 150,000 consumers per day. This woman-owned enterprise also helps to improve the lives of women street food vendors (the majority of its customers): having convenient access to precooked beans reduces drudgery and preparation/ cooking time, which also reduces their exposure to air pollution from cooking fuel.

I-Fit Cereal is a small business in Indonesia founded by a young woman and her mother in 2012. They aimed to leverage vegetables and fish that were currently being lost or wasted along the supply chain by processing them into nutritious products. One of their products is a nutritious cereal drink made with dried fish called I-Fit cereal, which has both a locally acceptable taste and high amounts of protein, iron, zinc, and calcium and which provides a useful way to process fish that might otherwise be lost (an estimated 75,000 - 125,000 MT of fish, or $20-35 \%$ of that produced, is lost annually in Indonesia). After winning a GAINsupported innovation challenge in 2019, the company received a large contract from Indonesia's Ministry of Marine Affairs and Fisheries and is on an impressive path to growth.

Zirakamwa Meza Nyanza Dairy was founded with the vision of it becoming the first choice for dairy consumers in Rwanda. Its founder noticed that safe, high-quality milk products were only available in supermarkets and boutiques, beyond the reach of lower-income consumers. Seeing this gap in the market, she wanted to make high-quality milk affordable and available to her community, especially for low-income consumers. Starting small, she invested her salary to buy a few cows and sell small amounts of raw milk as a second income stream. Eight years later, she now has two product lines (fermented milk and yogurt), quality and safety certifications, and a reach out to shops and institutions across the country. Her annual turnover grew over twentyfold in the company's first eight years. In the next five years, she plans to expand the factory to double production capacity, increase employment by $30 \%$, and introduce new smaller-sized products for low-income consumers. 


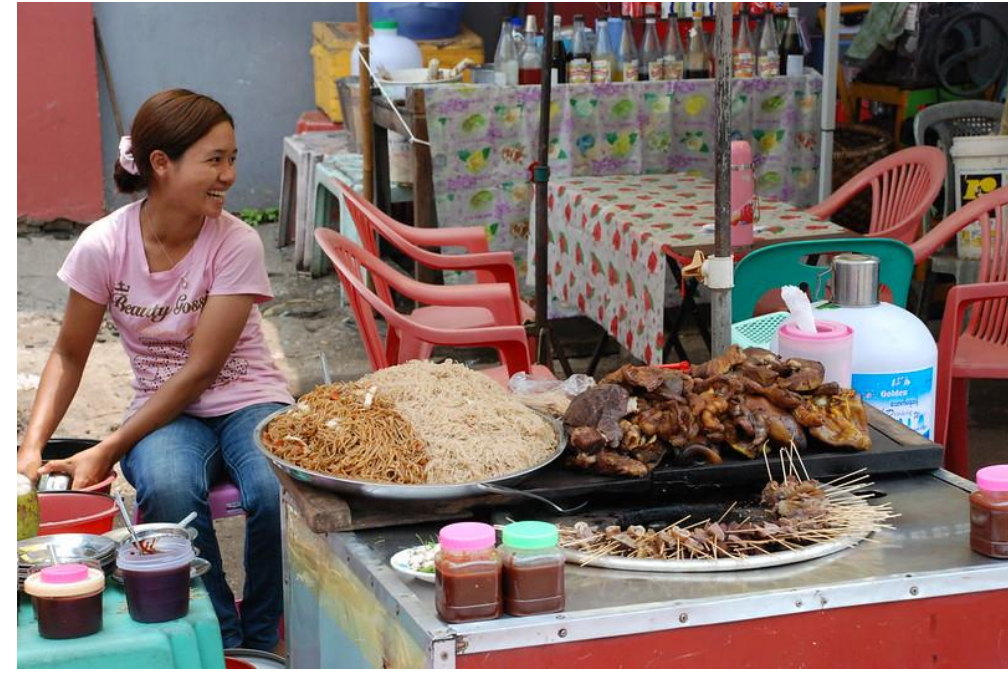

Figure 2. Women are over-represented in informal food vending, as for this female vendor in Myanmar.
Within the sector, women tend to be most associated with roles in informal food processing, vending, and catering, whereas men are more associated with wholesale, import/export, and formal bars and restaurants (20). In some settings, women wield significant amounts of power as key actors within food markets e.g., the 'market queens' of Ghana $(37,38)$. Along the value chain, exact, comparable numbers are lacking, but women tend to be prominent within

post-harvest handling and processing while being highly underrepresented in transportation and somewhat underrepresented in wholesale and formal-sector retail (e.g., supermarkets) some of the more lucrative sectors (39). This is partially due to limited freedom of movement and poor access to infrastructure and business networks (39). Women are also highly underrepresented in the more lucrative agricultural sectors: commercial, export, and contract farming (40). Among the barriers to women's engagement in higher agri-food productivity sectors such as commercial agriculture are limited social networks; lack of infrastructure, credit, technology, and training; gender norms and gender-based discrimination; and laws restricting women's access to resources (41). As shown in the next section, these barriers are similar to those faced by women entrepreneurs in other sectors.

One reason why women tend to be overrepresented in the food sector as compared to other fields of entrepreneurship is the relatively low start-up capital required (42)—this helps mitigate the large barriers women face to accessing finance (discussed in (43)). However, becoming formally registered as a food business can be onerous and costly, as it requires compliance with strict food safety rules, which can be difficult for poorly financed female entrepreneurs $(39,42)$. Indeed, some of the most burdensome business legislation is concentrated in the food industry. Research in Tanzania, for example, found that many small food enterprises would be unable to meet food control standards, were they enforced; this was found to be a greater barrier for women, due to smaller sizes of business, greater trouble finding formal premises that are food safety-compliant, and difficulty navigating the system (including its bureaucracy and corruption) ((44) in (20)). Women may also have less time for undergoing compliance processes, due to their double burden of work (20).

Women are thus more likely to start up micro-enterprises within the food sector than in other sectors, but commonly face larger barriers to formalising those businesses. As formal business registration is often a requirement for accessing financing, this can constitute a serious barrier to growth. 


\section{HOW DO WOMEN-OWNED BUSINESSES PERFORM COMPARED TO THOSE OF MEN?}

Regardless of the country, women's businesses in LMICs tend to be more likely to be informal and micro- or small-scale, less likely to employ others, grow more slowly, and be in lowergrowth sectors of the economy $(22,45,46)$. Indeed, the majority of women's enterprises in LMICs are 'micro' scale and never develop to become even 'small' businesses (27). While there is limited gender-disaggregated data available for businesses in the agri-food sector, specifically, women's roles within this sector likely mirror these overall trends. Indeed, research on horticultural value chains confirms that the challenges and opportunities faced by SMEs in this sector are similar to those seen in other sectors (47).

The low rates of business ownership, smaller scale, and concentration in particular subsectors of agri-food is unfortunate, as there are numerous potential advantages to women engaging in business-increased income, greater autonomy and agency, and increased social status $(21,42)$. There may also be social advantages to women in business. While there is very limited research examining the performance (i.e., revenues, profitability, efficiency) of women-owned businesses, as compared to men-owned businesses, in LMICs, research in the Philippines has indicated that women's businesses have better maintenance rates (46), and a study in India found women-owned businesses to have higher profit margins and lower nonperforming asset rates (48). A multi-region study, however, found female-owned firms lagged male-owned firms in terms of efficiency (49). Some evidence from East Africa suggests that women-owned firms create jobs at the same rate or higher than men-owned firms (20), while other research suggests women are more likely to employ other women $(50,51)$.

Evidence from high-income countries is mixed. Early research generally found that womenowned firms underperformed those of men $(17,52,53)$. More recent and sophisticated analyses have often refuted that finding, however. Some show no significant difference in firm performance for firms with female leaders (54) or women on corporate boards (55). Other analyses have found female entrepreneurs to outperform those of men on certain (but not all) indicators (56)(57). For example, a large 2017 meta-analysis using data from 46,000 firms showed a weak link between women in senior management and better long-term financial indicators for the firm (e.g., profitability, stock price) (58). In addition, a study of over 4,000 high-income country firms found that gender diversity helped foster greater innovation (59). Women-led firms or firms with women on boards have also been found to perform better when considered in terms of successful venture capital exits (60), valuations (61), return on equity and sales (62), volatility in returns (62), revenues (63), or profitability (64). ${ }^{4}$ There is also some, though mixed, evidence that women on corporate boards is associated with more women in managerial positions (65).

'Female' leadership styles have also been argued to have advantages within a business context, though this is disputed $(66,67)$. Reviews have found that women tend to be more likely to lead in ways considered by management experts to be highly effective, though the advantage is slight and most research comes from Western high-income contexts (66). Case studies of agribusiness firms in LMICs have found that women in management bring different perspectives and problem-solving strategies and can help foster innovation (68). In addition, companies with higher standards on these fronts also perform better on non-financial

\footnotetext{
${ }^{4}$ Of note, some researchers dispute the idea that 'success' should be measured by such metrics, particularly if growth and high profits are not the self-expressed goals of female entrepreneurs themselves (17).
} 
measures of business quality, such as stronger internal controls, lower fraud risk, and better reputation (69).

Finally, limited available research, mostly from high-income countries, suggests women have different approaches to decision making and different views of 'success' for their business (70) and are more likely than men to pursue social business missions in addition to economic ones $(17,70)$. Some work (summarised in (69) and primarily from highincome countries) suggests the women in leadership is associated with higher environmental, social, and governance standards for the firm. There are a few findings from LMICs that seem to confirm that women see businesses at helping to contribute to society, not just their own advancement, at least within certain contexts (71).

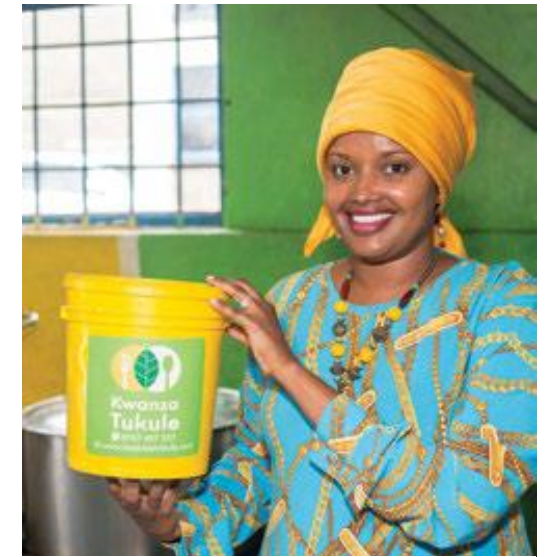

Figure 2. Kwanza Tukule is a successful woman-owned food system enterprise with a social mission (See Box 1)

Women thus tend to be underrepresented among entrepreneurs and business leaders worldwide, despite having a large role in the food system firms as a whole. Women in businesses can have personal and social advantages, but their firms often remain informal, small- or micro-sized, and low growth. The next section discusses some of the reasons behind these trends.

\section{BARRIERS TO WOMEN'S ENGAGEMENT IN BUSINESS IN LMICS}

Entrepreneurs in LMICs face considerable challenges when starting and growing businesses. Starting a small business in an LMIC can be extremely time consuming, taking over 100 days in some countries, and expensive, costing about half of average per capita annual income in Kenya and Nigeria, for example. Licensing and registering property can also take several months and cost over $100 \%$ of annual per capita income (72). The cost and complexity of registration makes it difficult for many SMEs to comply (27). Indeed, a large share of people in LMICs avoid these challenges and remain in the informal economy; in Mozambique, for example, $95 \%$ of the working population works in the informal economy (19). In some settings, tax codes can be complex and corruption and bribery common (e.g., (73)). A lack of affordable, appropriate business premises is also a limitation on the growth of entrepreneurial ventures (27).

However, women face additional barriers to business entry and growth, due to lower initial financial, human, physical, and social capital as well as less time and mobility. These are due to both discriminatory social/cultural norms and to unequitable institutional structures and policies, resulting in under-investment in women and barriers to them acquiring additional capital $(50,74,75)$. These barriers are discussed in the following subsections. While they are not specific to the agri-food sector, most of them likely apply equally in that sector as in others. 


\section{Knowledge, Skills, and Information}

In some LMICs, women's endowments of human capital relevant to starting and running a business tend to be smaller than those of men. Due to lower historic access to education, many women in LMICs have worse literacy and numeracy and more limited education than men (in low-income countries, $56 \%$ of women are literate, versus $71 \%$ of men, (76)). This may constrain their ability to engage in the business world and develop this business-specific knowledge and skills $(77,78)$. Women may also have more limited knowledge of specific business-relevant topics, like legal obligations, scant financial literacy, limited accounting and management skills, due to biases in education (both formal and informal), and less confidence when negotiating access to finance with financial institutions due to limited understanding of financial language and relevant laws (19,50,79-83). Women's access to information can be further limited by their more limited access to the internet (27) or reliance on simpler, limited-functionality mobile phones $(84,85)$. Women may also lack access to key production technologies, leaving them reliant on more time-consuming processes or lowerquality outputs (79). Women may also have difficulty mobilising the human capital embedded in family labour (i.e., by employing their sons, daughters, or other relatives), if their use of them is seen as being in competition with that of the men in the household.

\section{Access to Financial Capital}

The topic of gender equity in business financing for food system firms is discussed in detail in (43). In brief, credit and capital are crucial for business growth, but there is a global gender gap in finance access (86). In emerging markets, just $7-11 \%$ of investment goes to female entrepreneurs or founders (61). This financing gap relates to not only quantity but also quality, with women business owners in Africa often borrowing smaller amounts and on worse terms $(22,87)$. Causes of this financing gap are similar to those noted above - inadequate financial literacy, more limited mobility and access, limited business experience and expertise, gender norms that favour men and male-led firms, and stereotypes about women's enterprises being low growth, marginal, micro, and locally focused (88). Discriminatory legal structures and poorer access to land or other assets to use as collateral also play a role.

Lacking funds to acquire or rent premises, women often must run their business out of the home (89): many women-owned businesses have either no or inadequate premises for their operations (though this is less true for those that are formal and medium-sized, as opposed to micro enterprises (20)). Inadequate or home-based premises place limitations on growth.

\section{Home Responsibilities}




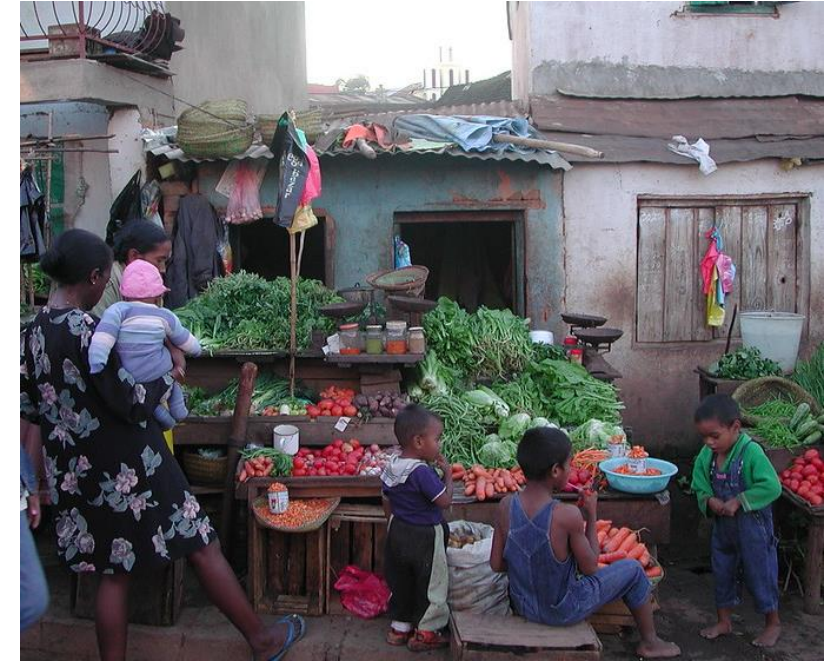

Figure 3. Women entrepreneurs must often juggle caring for children with doing their work, as for this vegetable seller in Tanzania.

Women often have larger burdens of unpaid domestic or social work (e.g., caring for children or elders); this can increase the opportunity cost of their time and may give them less time and schedule flexibility to engage in business and entrepreneurship $(46,82,90,91)$. For example, the time-consuming nature of business registration processes can pose a high barrier to women formalising their businesses (42). As female entrepreneurs in LMICs rarely have access to maternity leave, having a baby can be challenging for their business $(23,92)$. Both social norms about women's roles in the home and official policies (e.g., parental leave, statesponsored childcare, and school hours) can reinforce this $(50,93)$. In a survey of female entrepreneurs in the Middle East and North Africa (MENA), as well as in a case study of female entrepreneurs in Ghana, balancing work responsibilities with family life was the highest-rated challenge $(73,94)$.

It has also been argued that women tend to spend most of their business income on family food, children's clothing and education, limiting the amount they re-invest in the business to grow it (80). They may also be pressured by household members or social norms to use the money for household expenses, not business ones $(71,80,91,95)$. Research from Ghana also suggests that women may hide business income or even explicitly limit business growth in order to reinforce the cultural idea that their husband is responsible for being the primary provider (95). However, some studies have found that female entrepreneurs see their business as not impacting or even improving their family relationships, perhaps due to a greater ability to contribute to household expenses (96).

\section{Mobility}

Some women in LMICs also face restrictions on their freedom of movement. This can be due to explicit social norms (as in some conservative Muslim societies), the risk of violence (particularly gender-based violence), or to home obligations or poorer access to affordable transport $(39,71,91,97)$. Safety and security issues also tend to disproportionately affect women entrepreneurs, and actual or perceived risk may further limit their ability to work outside of the home (98). These mobility restrictions can limit women's ability to source inputs and equipment, meet partners, sell their products, and attend trade fairs and similar events $(23,24,42,99)$. It can also restrict them to operate only in local markets, which may be more competitive and lower value than the main urban and export markets $(39,77)$.

\section{Social Norms and Attitudes}

Women may also need to confront negative social attitudes, which can be a barrier to engaging in entrepreneurship $(20,90,97,100)$. These social attitudes can result in being 
unable to access resources; having limited ability to own assets or enter into contracts; having limited opportunities to gain management experience; and being restricted in terms of how and where they can work $(20,24)$. Such attitudes can greatly restrict women's agency. Women may also face increased risk of harassment (including sexual harassment) or bribe requests from (predominantly male) officials and businessmen $(39,42)$, particularly in settings where corruption is common (98). Many of these issues are rooted in deeply held cultural beliefs about women playing a subordinate role to men (e.g., in Nigeria (90)).

Over half of women surveyed in Mozambique, for example, felt it was easier for men than women to manage a business due to the difficulties of managing male employees, balancing work and family, and being taken seriously as a female business owner (19). Studies of female entrepreneurs in Nigeria, India, and China similarly found that $80-84 \%$ of them felt it was easier for a man to succeed in business than a woman $(90,97)$. In a study in Tanzania, some women entrepreneurs reported that they had difficulty personally closing deals with officials or suppliers, who insisted on negotiating with their husbands, instead (42). In Pakistan, women entrepreneurs surveyed named gender biases as the main barrier to starting a business, including hostile attitudes of men, challenges dealing with male workers, and negative social perception of businesswomen (50). In another study, Pakistani female business owners reported challenges in proving their credibility to suppliers and customers (99). In Malaysia, certain social norms dictate that women should lead 'as if they were mothers of teachers' - not in a formal role, as a business leader. Indeed, Malaysian women reported their microenterprises being taken over by a husband or male relative once the business grew to become more successful (98). Some studies have also found that women leaders and managers are more likely to have their authority or leadership questioned by male colleagues $(66,101)$, particularly as leadership and management have been construed as primarily 'masculine' activities and associated with stereotypically masculine qualities (66). Women leaders may also be held to higher standards of competence and judged more harshly for mistakes (66). Most research on women in leadership, however, comes from high-income Western countries; it is also possible that such stereotypes about women in leadership roles may be less influential in the food sector, which tends to be traditionally associated with women.

At the same time, some cultures have positive associations with women in business; in the Philippines, for example, women are reported to be more patient, tactful, and persuasive and better at networking and handling finances (46). In general, however, gender stereotypes related to business tend to favour men.

\section{Psychological Barriers}

There may also be psychological barriers arising from ingrained social norms that place women in a lower social position: female entrepreneurs in LMICs are often less likely than men to have confidence in their skills or see themselves as a strong leader $(23,79,93)$. In social contexts such as parts of Africa or South Asia, where women are expected to be subservient or not speak in public, they may need considerable coaching to become 'outgoing' within a professional, business context (79). Negative social attitudes and similar barriers can also operate to limit the pool of women entrepreneurs, as they may deter women from considering business ownership as an option or lower their self-perceived agency; this 
'self-selection' helps perpetuate gender-inequitable social norms related to women in business (20). In addition, women's enterprises tend to suffer from being stereotyped as low growth, marginal, micro, and locally focused (88)-all of which can lower the interest of investors, financial institutions, business development services, and business networks in supporting them, creating a self-fulfilling cycle of limited enterprise development (27). It is thus essential to recognise and accommodate the unique challenges that women entrepreneurs face without reinforcing such stereotypes.

\section{Networks and Mentors}

Having access to entrepreneurial role models can be a key factor in starting a business, but many female entrepreneurs identify a lack of mentorship as a major challenge for their business (51). Women in LMICs often have limited exposure to female business owners $(83,98)$ - particularly of medium-sized or large businesses_and gender norms may also prevent women from being mentored by men, which is problematic when there are limited female mentors available. In some cultural contexts, it may also be unacceptable for women to have male employees (24). At the same time, women's own social networks (which, in LMICs, are often women-dominated) can be rich sources of support (71). This topic is covered in more detail in a companion paper (102).

\section{Laws, Policies, and Infrastructure}

Finally, in LMICs there are numerous constraints imposed by the larger economic climatee.g., poor infrastructure and government services and unsupportive policies $(22,82)$. Micro- or small-scale firms tend to be more vulnerable to such effects; for example, they cannot afford a generator to buffer power outages or to hire security services to make up for lacklustre policing (22). As women's businesses are more likely to be micro-scale or small, this disproportionately impacts them. In addition, the World Bank reports that (as of 2016) over 170 countries have at least one law impeding women's participation in the economy, such as rules for obtaining national ID cards that vary by gender and that on average (as of 2020), women have only $75 \%$ of the legal rights afforded to men $(103,104)$. This may mean that they lack the official identification documents needed to register a business or obtain a loan (21).

\section{BUSINESSWOMEN AND ACCESS TO SUPPORTING SERVICES}

Business and management skills can be a major barrier to the growth and success of SMEs and women-owned SMEs in particular. A study in Mozambique found that $29 \%$ of women business owners felt they lacked the key skills for managing their businesses, especially in financial management, human resources management, and marketing, and less than $10 \%$ of the women had key technical skills (19). Over three-quarters of businesswomen surveyed in the Middle East and North Africa region felt they needed training on general business management skills in order to grow their business (26). These poor management skills and lack of training are key causes of failure among SMEs. Businesswomen also often face difficulties accessing programmes run by financial institutions, governments, or NGOs because they are unable to prepare the required business plans $(19,25,75,79)$. Moreover, many women entrepreneurs in LMICs remain in the informal economy-e.g., 59\% of informal workers in Mozambique are women (19)_because of the (actual or perceived) challenge to obtaining formal registration and licensing (19). This can constrain the business's growth, 
complicate accessing financial services, and leave the business and its owner in a precarious position.

All of these issues could potentially be addressed by business development services (BDS). BDS include non-financial support with product development, strategy, diversification, or growth; this can include training in management techniques as well as developing business plans, marketing strategies, and similar. Most general BDS are applicable across sectors, but some are particularly relevant to the food sector, such as supply chain management, quality assurance/control, and support with navigating certification and regulation related to food safety. BDS can help improve business performance under some circumstances, though evidence is somewhat mixed (105-110). However, many female entrepreneurs in LMICs lack access to these services at affordable prices or do not know they exist $(19,79)$. In Zambia, for example, only $30 \%$ of female entrepreneurs had used BDS despite $90 \%$ of them indicating a need for business support (42). Similar results were found in Pakistan (50). Low receipt of business training and development services among women has also been documented in East Asia and the Pacific (111).

Reasons for low use of BDS by women include that quality BDS are lacking in many LMIC settings (42), and discerning which are high-quality and which are not can be problematic (25). Existing BDS appear to either not be reaching many women or not meeting their needs in many LMICs $(19,42,92)$. Many BDS are concentrated in urban areas, with limited outreach to rural zones. Not only are many women-owned SMEs based in rural areas (27), but travelling to distant cities can be particularly difficult for women, who (as discussed above) face barriers to mobility and have many demands placed on their time through their burden of household care work (19). Such barriers have been found in East/Southern Africa, India, Pakistan, and Indonesia $(20,24,50)$. Moreover, many women would prefer female BDS providers, particularly in settings with strong gender norms that make it difficult for a woman to meet with a male non-relative one-on-one. However, there are few women BDS advisors (27). It has also been argued that business finance and support providers tend to see women entrepreneurs more in terms of prevention of financial risk and male entrepreneurs in terms of positive growth potential (112). Such attitudes may result in poor-quality service provision. Finally, where quality BDS services do exist, women may be unable to pay for them (42).

There is some limited evidence that BDS specifically tailored to women can help them to grow their businesses (113), and improved access to BDS is one of the ten steps recommended by the International Labour Organisation (ILO) to help women grow their businesses (114). However, there are few BDS or training programmes tailored to women in LMICs (77); where such programmes do exist, they are often geared at traditionally 'feminine' industries (46), such as hairdressing or small-scale food processing. They are often included as part of microfinance institutions or loan programmes and thus focused on loan repayment and financial management, neglecting other key aspects of growing a business, such as marketing (20). Moreover, business support programmes may require women to attend basic training below their skill level, which can discourage participation (42)_particularly among women who already have limited time due to their dual work burden. It is thus essential not to take a one-size-fits-all approach when considering BDS for women: while some women 
may lack basic entrepreneurship skills, others may be highly educated, growth-oriented, and in need of advanced training.

In addition to personalised BDS, some group-based general entrepreneurial training is available in most LMICs, sometimes provided through donor funding, but it tends to be poorly adapted to women's needs. Training is typically multi-day and focused in urban centres, but many women cannot travel to training sessions or be away from their families or businesses for several days (27). Entrepreneurs' husbands may object to participation in training led by men, who comprise most enterprise trainers in LMICs. Such training often tends to be general and not growth-oriented (27) and lacking in follow-up support, which can particularly important to women with less entrepreneurial experience. Few business schools or other educational institutions in LMICs integrate entrepreneurship into their degree programmes (27), and women tend to be underrepresented in such formal education programmes (e.g., comprising less than one third of students in graduate management programmes in Africa (115)).

Some research has found that women entrepreneurs may not need specific women-tailored services, but rather service providers who are sensitive to gender concerns (51), whereas other authors contend that women entrepreneurs tend to have different support needs than men (62).

\section{CAVEATS \& RESEARCH GAPS}

This review has highlighted the challenges that women face in entrepreneurship, largely because prior research has tended to focus primarily on challenges (often in order to inform policy or programming to address these). There is very limited information detailing successful ways in which women cope with the barriers they face or analysing potential advantages women may face when engaging in business. However, it is important to note that there are also advantages to being a female entrepreneur (e.g., better understanding of female consumers' needs). Indeed, women entrepreneurs themselves often take more nuanced views of how gender impacts their business, seeing both advantages and downsides (94). Some see their being female as not having an important influence on their business success or even helping their career $(90,97)$. There are also many examples of successful female entrepreneurs, including in the agri-food sector (see Box 1). In addition, while this review has focused primarily on women as business owners, other business models (including those owned by men) can empower women as employees, suppliers (e.g., farmers), and distributors (e.g., door-to-door saleswomen).

Further, many barriers to engaging in entrepreneurship and business in LMICs are faced by men as well as women-even if some may be higher for women then for men. Women entrepreneurs in LMICs are also not a homogenous group, and gender is only one component of identity; the opportunities and constraints women face thus vary widely, including by characteristics such as age and race or ethnicity (116-118). There are thus numerous exceptions to the general tendencies discussed here (20). Moreover, such stereotypes can prove to be self-fulfilling if they discourage women from entering business or pursuing ambitious business goals. As such, it is important not to assume such generalisations apply to all women-owned firms, to avoid reinforcing them, and to make it 
clear that many of these tendencies are driven by the barriers women face within the business sector-linked to underlying social norms and structures—not by the innate characteristics of women, per se.

The analysis also did not distinguish among micro, small, or medium-sized firms. This was due to limited distinction between them in the literature. However, it is clear that food system MSMEs is a diverse category and some barriers and opportunities will be more relevant to the smallest or newest firms, while others are more relevant for the larger or more developed ones. For example, illiteracy and poor numeracy are likely to be more important barriers for micro-enterprises, as it would be hard for an entrepreneur to have reached the level of owning a medium-scale enterprise without overcoming these barriers. However, any barrier at any point in the firm-development process could prevent women from becoming successful entrepreneurs and growing their businesses, making the barriers faced by microentrepreneurs also relevant for understanding a potential lack of successful larger womenowned firms.

It should also be noted that there is limited information available on women's entrepreneurship, with just $10 \%$ of studies in the field of entrepreneurship focusing on this topic and the vast majority of these undertaken in Western, high-income countries (70). The data that does exist on women business owners is concentrated on a few countries and by a few organisations, such as the ILO and International Finance Corporation. There is particularly little information specific to women within the agri-food sector, beyond smallholder farmers. Given the overall limited information, this review did not screen references for quality nor did it exclude papers published in 'predatory' journals; as such, it must be kept in mind that the quality of some of the evidence included here is not high.

In addition, this review has focused on more proximal factors influencing women's participation in business, such as financing and BDS. However, the larger enabling environment also plays an essential role: through policies on gender-based discrimination, parental leave, child care, property rights, flexible work, and business regulation, governments could do much to improve the situation of women entrepreneurs and employees alike (27). Increasing women's agency to access resources and make decisions is also crucial and depends on addressing underlying social norms and roles. Working to reduce women's dual work burden through drudgery-reduction technology and/or more sharing of work within the household would also free up women to spend more time on business. Most of the approaches used thus far to support women in business in LMICs (e.g., providing women-tailored BDS, funding mechanisms for women, women's business networks) have been gender-sensitive (see Box 3): they recognise and adapt to existing gender inequities and gender-related barriers, without trying to change those underlying norms. To date, there have been few attempts to develop gender-transformative approaches-i.e., those that aim to alter the underlying social norms that make it more difficult for women than men to engage in business. Doing so would require work with both men and women to address stereotypes around women in business, gender roles and division of labour within and outside the home, and how men and women interact (e.g., as employers and employees, or as funders and recipients). 
Finally, it was noted above that research suggests women may be more likely than men to pursue social business missions in addition to economic ones $(17,70)$. When considering women in the food sector, and with the particular lens of nutrition, a key question remained unanswered: whether women-owned businesses, or businesses with a larger number of women employees, tend to produce or support more nutritious foods than those owned by men. Understanding this would help to determine how central the targeting of womenowned firms should be to initiatives that aim to support agri-food companies in order to increase population-level access to nutritious foods (e.g., GAIN's Marketplace for Nutritious Foods programme, Box 2). Prior work on women in agriculture has suggested that resources spent on women (or increasing women's own resources) pay greater social dividends for the household than equivalent investment in men; it is unclear whether such an argument may hold when considering support to SMEs (as opposed to farmers) and societal benefits (as opposed to household-level ones).

\section{CONCLUSION \& RECOMMENDATIONS}

Based on the results of this reviewed literature, certain recommendations can made for how to better integrate gender equity into programmes that support food system MSMEs-such

\section{BOX 2. THE MARKETPLACE FOR NUTRITIOUS FOODS PROGRAMME}

2020) with the aim of supporting MSMEs in nutritious food value chains to develop profitable business models and sustainably bring more nutritious and safe foods to market in LMICs. The Marketplace uses a two-pronged approach: supporting a broad network of stakeholders with information and knowledge through the Community of Practice and providing targeted technical and financial support to promising, innovative firms through the Innovation Accelerator. The Community of Practice creates a network of entrepreneurs and others interested in knowing more about how businesses can contribute to improved supply of nutritious and safe foods for local markets (e.g., universities, regulatory bodies, non-governmental organisations). It convenes regularly for networking events and trainings on topics related to both general business skills (e.g., marketing) and those specific to the food sector (e.g., food safety). The Innovation Accelerator supports investible, nutritionenhancing business ideas across food value chains. After careful review, promising proposals are eligible for technical assistance to support business planning and product development. Selected companies become eligible to receive grant funding and technical assistance to support the implementation of the business plan. With funding from the Netherlands Ministry of Foreign Affairs, UK Department for International Development, and the United States Agency for International Development, GAIN has so far provided targeted technical assistance to over 100 MSMEs in four countries. 
as GAIN's Marketplace for Nutritious Foods (Box 2). Most of these are not unique to food system firms, per se, and would apply to other types of MSMEs, as well. Recommendations for improving women's access to capital and financing and business networks are discussed in companion papers $(43,102)$.

First, such initiatives should be built on an understanding of the gender dynamics, norms, and gendered barriers specific to the market in question. They should be promoted through women's business associations, incubators, and other networks for female entrepreneurs. In deciding which firms and products to support, they should assess the business case for each company/product using a gender lens: are women/girls examined as consumers and does that analysis differentiate among different types of women/girls (and men/boys)? As feasible, they should prioritise products/services and business models that will disproportionately benefit women and girls. Decisions on which firms to support should not be made by singlegender panels.

For any events (including the selection process for receiving support), implementers should assess the needs of both men and women in terms of event timing (considering family responsibilities, mobility limitations, etc.) and format, and adapt to meet those needs. Technical assistance and financing should be based on detailed needs assessments to ensure that support is tailored to the needs of each entrepreneur/business, without assuming women-owned firms have different needs-but allowing them to. This can include training on navigating financial services, negotiation and assertive communication, and gender issues in the workplace. Technical assistance can also support firm leaders to better serve women and girls as consumers, suppliers, or distributors and to develop gender equity-fostering workplace policies and practices. Programmes can also pair successful women food entrepreneurs (e.g., supported applicants) with women owners of less-developed businesses (e.g., unsuccessful applicants) for mentoring.

Finally, it is important for such initiatives to integrate gender into their monitoring and metrics. This includes understanding the main factors that disqualify firms from being selected for support and whether these differ across male- and female-owned firms as well as the gender breakdown of any service providers used. Key metrics should be genderdisaggregated where relevant, and the quality of any services provided should be closely monitored to ensure they meet the needs of both male and female entrepreneurs.

Gender gaps in business are widespread, with women being less likely to engage in entrepreneurship and often facing larger barriers to doing so-including with regards to poor access to finance and busines development services, lower education and literacy, gender stereotypes and discrimination, limitations on mobility, and a dual burden of professional duties alongside unpaid care work. However, there are many examples of successful womenled firms, including in the food systems of LMICs. By integrating the abovementioned recommendations into their design, programmes aiming to support food system MSMEs can make their work more gender equitable. In the longer run, however, more gendertransformative approaches will be needed, including those that address structural barriers to women's entrepreneurship and those that work with both men and women to address stereotypes around women in business and gender roles and norms. 


\section{BOX 3. KEY GENDER-RELATED TERMINOLOGY}

Gender - A social and cultural construct distinguishing differences in the attributes of men and women, girls and boys. Gender refers to expectations about the roles, responsibilities, characteristics, aptitudes, and behaviours of women and men.

Gender equality - The equal rights, responsibilities, and opportunities of women and men, girls and boys, irrespective of being born male or female (and not implying equal outcomes).

Gender equity - The process of being fair to men and women, boys and girls, and importantly the equality of outcomes and results.

Gender blind - Not recognising that the roles and responsibilities of men/boys and women/girls vary and are partially dictated by their specific contexts and backgrounds (119).

Gender sensitive - Programmes and policies that are aware of and work with or around gender differences (119).

Gender transformative - Programming and policies that work to transform gender relations to achieve gender equity and other goals to which gender equity is instrumental (119). 


\section{REFERENCES}

1. Development Initiatives. Global Nutrition Report 2017: Nourishing the SDGs. Bristol: Development Initiatives; 2017.

2. Global Alliance for Improved Nutrition (GAIN), Johns Hopkins University. The Food Systems Dashboard [Internet]. Global Alliance for Improved Nutrition (GAIN) and Johns Hopkins University; 2020 Jun [cited 2020 Sep 24]. Available from: https://foodsystemsdashboard.org/

3. GloPan. Food Systems and Diets: Facing the Challenges of the 21st Century. London: Global Panel on Agriculture and Food Systems for Nutrition (GloPan), UK.; 2016.

4. Tschirley DL, Snyder J, Dolislager M, Reardon T, Haggblade S, Goeb J, et al. Africa's unfolding diet transformation: implications for agrifood system employment. Steven Haggblade, Dr John B. Kaneen D, editor. J Agribus Dev Emerg Econ. 2015 Nov 16;5(2):102-36.

5. Sibhatu KT, Qaim M. Rural food security, subsistence agriculture, and seasonality. PloS One. 2017;12(10):e0186406.

6. Gelli A, Donovan J, Margolies A, Aberman N, Santacroce M, Chirwa E, et al. Value chains to improve diets: Diagnostics to support intervention design in Malawi. Glob Food Secur. 2019 Oct 1;

7. Demmler K. The Role of Small and Medium-Sized Enterprises in Nutritious Food Supply Chains in Africa [Internet]. Global Alliance for Improved Nutrition (GAIN); 2020 Apr [cited 2020 May 25]. Available from: https://www.gainhealth.org/sites/default/files/publications/documents/gain-workingpaper-series-2-the-role-of-small-and-medium-sized-enterprises-in-nutritious-foodsupply-chains-in-africa.pdf

8. Reardon T. The hidden middle: the quiet revolution in the midstream of agrifood value chains in developing countries. Oxf Rev Econ Policy. 2015 Mar 1;31(1):45-63.

9. Wikipedia. Small- and medium-sized enterprises [Internet]. Wikipedia. [cited 2020 Sep 29]. Available from: https://en.wikipedia.org/wiki/Small_and_medium-sized_enterprises

10. Reardon T, Mishra A, Nuthalapati CS, Bellemare MF, Zilberman D. COVID-19's Disruption of India's Transformed Food Supply Chains. Econ Polit Wkly. 2020 May 2;LV(18).

11. Reardon T, Bellemare MF, Zilberman D. How COVID-19 may disrupt food supply chains in developing countries [Internet]. IFPRI Blog. 2020 [cited 2020 May 25]. Available from: https://www.ifpri.org/blog/how-covid-19-may-disrupt-food-supply-chains-developingcountries

12. ILO. Small matters: Global evidence on contributions to employment by the selfemployed, micro enterprises and SMEs. Geneva: International Labour Organization; 2019.

13. AGRA. The Hidden Middle: A Quiet Revolution in the Private Sector Driving Agricultural Transformation. Nairobi: Alliance for a Green Revolution for Africa (AGRA); 2019. (AGRA African Agriculture Status Report 2018). 
14. Grant MJ, Booth A. A typology of reviews: an analysis of 14 review types and associated methodologies: A typology of reviews, Maria J. Grant \& Andrew Booth. Health Inf Libr J. 2009 Jun;26(2):91-108.

15. Munn Z, Peters MDJ, Stern C, Tufanaru C, McArthur A, Aromataris E. Systematic review or scoping review? Guidance for authors when choosing between a systematic or scoping review approach. BMC Med Res Methodol. 2018 Dec;18(1):143.

16. Arksey H, O'Malley L. Scoping studies: towards a methodological framework. Int J Soc Res Methodol. 2005 Feb 1;8(1):19-32.

17. Jennings JE, Brush CG. Research on Women Entrepreneurs: Challenges to (and from) the Broader Entrepreneurship Literature? Acad Manag Ann. 2013 Jun;7(1):663-715.

18. Dawson C, Fuller-Love N, Sinnott E, O'Gorman B. Entrepreneurs' Perceptions of Business Networks: Does Gender Matter? Int J Entrep Innov. 2011 Nov;12(4):271-81.

19. ILO. The Enabling Environment For Women In Growth Enterprises In Mozambique: Assessment Report. Geneva: Cilo Conulsting for the ILO; 2011. (WEDGE Southern Africa Program).

20. Richardson $P$, Howarth R, Finnegan $G$. The challenges of growing small businesses: Insights from women entrepreneurs in Africa. Geneva: ILO; 2004. (SEED Working Paper). Report No.: 47.

21. ICRW. Women Entrepreneurs Need More Than Capital. Washington, DC: International Center for Research on Women (IRW); 2019.

22. GPFI, IFC. Strengthening Access to Finance for Women-Owned SMEs in Developing Countries. Washington, DC: Global Partnership for Financial Inclusion (GPFI) and International Finance Corporation (IFC); 2011.

23. Korreck S. Women Entrepreneurs in India: What is Holding Them Back? Observer Research Foundation (ORF); 2019. Report No.: ORF Issue Brief 317.

24. Tahi Hamonangan Tambunan T. Development of small and medium enterprises in a developing country: The Indonesian case. McKague K, editor. J Enterprising Communities People Places Glob Econ. 2011 Mar 29;5(1):68-82.

25. Karim NA. Jobs, Gender and Small Enterprises in Bangladesh: Factors Affecting Women Entrepreneurs in Small and Cottage Industries in Bangladesh. Geneva: International Labour Organization; 2001.

26. IFC. Ready for Growth: Solutions to Increase Access to Finance for Women-Owned Businesses in the Middle East and North Africa. International Finance Corporation (IFC); 2013.

27. ILO. Support for Growth-oriented Women Entrepreneurs in Ethiopia, Kenya and Tanzania. Geneva: International Labour Organization; 2005.

28. IFC. Exploring the Opportunities for Women-owned SMEs in Cambodia. Washington, DC: International Finance Corporation (IFC); 2019.

29. Palacios-Lopez A, Christiaensen L, Kilic T. How much of the labor in African agriculture is provided by women? Food Policy. 2017 Feb;67:52-63. 
30. FAO. The state of food and agriculture: Women in agriculture. Closing the gender gap for development. Rome: Food and Agriculture Organization of the United Nations; 2011.

31. Allen $T$, Heinrigs $P$, Heo I. Agriculture, Food and Jobs in West Africa [Internet]. Paris: OECD; 2018. (West African Papers). Report No.: 14. Available from: https://www.oecdilibrary.org/content/paper/dc152bc0-en

32. Singh SP, Reynolds RG, Muhammad S. A Gender-Based Performance Analysis of Micro and Small Enterprises in Java, Indonesia. J Small Bus Manag. 2001 Apr;39(2):174-82.

33. Ghani E, Kerr WR, O'Connell SD. What Explains Big Gender Disparities in India? Local Industrial Structures and Female Entrepreneurship. Washington, DC: World Bank; 2012. Report No.: 6228.

34. Ferdinand C. Jobs, Gender, and Small Enterprises in the Caribbean: Lessons from Barbados, Suriname and Trinidad and Tobago. Geneva: International Labour Organization; 2001. (WEDGE Paper Series).

35. Aluko OO, Ojeremi TT, Olaleke DA, Ajidagba EB. Evaluation of food safety and sanitary practices among food vendors at car parks in Ile Ife, southwestern Nigeria. Food Control. 2014 Jun;40:165-71.

36. Nurudeen, AA, Lawal, AO, Ajayi, SA. A survey of hygiene and sanitary practices of street food vendors in the Central State of Northern Nigeria. J Public Health Epidemiol. 2014 May 19;6(5):174-81.

37. Robertson C. Economic Woman in Africa: Profit-Making Techniques of Accra Market Women. J Mod Afr Stud. 1974;12(4):657-64.

38. Scheiterle L, Birner R. Gender, knowledge and power: A case study of Market Queens in Ghana. In Washington, DC; 2018.

39. IFC. Investing in Women along Agribusiness Value Chains. Washington, DC: International Finance Corporation (IFC); 2016.

40. Croppenstedt AG Markus Rosas, Nina. Gender and Agriculture: Inefficiencies, Segregation, and Low Productivity Traps. World Bank Res Obs. 2013 Feb 1;28(1):79109.

41. Peters H, Irvin-Erickson Y, Adelstein S, Malik A, Derrick-Mils T, Valido A, et al. Qualitative evidence on barriers to and facilitators of women's participation in higher or growing productivity and male-dominated labour market sectors in low- and middleincome countries. London: EPPI Centre, Social Science Research Unit, UCL Institute of Education, University College London; 2019.

42. ILO. Zambian Women Entrepreneurs: Going for Growth. Geneva: International Labour Organization; 2003.

43. Nordhagen S. Supporting Gender Equitable Food Systems through Access to Business Finance. Geneva, Switzerland: Global Alliance for Improved Nutrition (GAIN); 2020. Report No.: GAIN Working Paper 13. 
44. University of Dar es Salaam Entrepreneurship Centre (UDEC). Jobs, Gender and Small Enterprises in Africa: Women Entrepreneurs in Tanzania. A Preliminary Report. Geneva: International Labour Organization; 2002.

45. Spring A. African Women in the Entrepreneurial Landscape: Reconsidering the Formal and Informal Sectors. J Afr Bus. 2009 Mar 10;10(1):11-30.

46. Marcucci PN. Jobs, gender and small enterprises in Africa and Asia: Lessons drawn from Bangladesh, the Philippines, Tunisia and Zimbabwe. Geneva: International Labour Organization; 2001.

47. Staritz C, Reis JG. Global Value Chains, Economic Upgrading, and Gender: Case Studies of the Horticulture, Tourism, and Call Center Industries. Washington, DC: World Bank; 2013.

48. Singh R, Chhabra P. Financial Inclusion for Woman-Owned Micro, Small \& Medium Enterprises (MSMEs) in India. Washington, DC: International Finance Corporation (IFC);

49. Bardasi E, Sabarwal S, Terrell K. How do female entrepreneurs perform? Evidence from three developing regions. Small Bus Econ. 2011 Nov;37(4):417-41.

50. Goheer N. Women entrepreneurs in Pakistan, how to improve their bargaining power. Geneva: International Labour Organization; 2003.

51. Holzman C, Roberts-Robbins K. Serving the financial needs of women-owned businesses in emerging markets: Perspectives from the Dutch Good Growth Fund. The Hague: Netherlands Ministry of Foreign Affairs / Dutch Good Growth Fund; 2019.

52. Du Rietz A, Henrekson M. Testing the Female Underperformance Hypothesis. Small Bus Econ. 2000;14(1):1-10.

53. Fairlie RW, Robb AM. Gender differences in business performance: evidence from the Characteristics of Business Owners survey. Small Bus Econ. 2009 Dec;33(4):375-95.

54. Watson J. Comparing the Performance of Male-and Female-Controlled Businesses: Relating Outputs to Inputs. Entrep Theory Pract. 2002 Apr 1;26(3):91-100.

55. Pletzer JL, Nikolova R, Kedzior KK, Voelpel SC. Does Gender Matter? Female Representation on Corporate Boards and Firm Financial Performance - A Meta-Analysis. Huerta-Quintanilla R, editor. PLOS ONE. 2015 Jun 18;10(6):e0130005.

56. Sabarwal S, Terrell K. Does Gender Matter For Firm Performance? Evidence From Eastern Europe And Central Asia [Internet]. The World Bank; 2008 [cited 2020 May 27]. (Policy Research Working Papers). Available from: http://elibrary.worldbank.org/doi/book/10.1596/1813-9450-4705

57. Abouzahr K, Taplett FB, Krentz M, Harthorne J. Why Women-owned Startups are a better bet. Boston: Boston Consulting Group (BCG); 2018.

58. Jeong S-H, Harrison DA. Glass Breaking, Strategy Making, and Value Creating: MetaAnalytic Outcomes of Women as CEOs and TMT members. Acad Manage J. 2017 Aug;60(4):1219-52.

59. Díaz-García C, González-Moreno A, Jose Sáez-Martínez F. Gender diversity within R\&D teams: Its impact on radicalness of innovation. Innovation. 2013 Jun;15(2):149-60. 
60. Brush C, Greene P, Balachandra L, Davis A. The gender gap in venture capital- progress, problems, and perspectives. Venture Cap. 2018 Apr 3;20(2):115-36.

61. IFC. Moving toward gender balance in private equity and venture capital. Washington, DC: International Finance Corporation (IFC); 2019.

62. Maheshwari P, Gokhale A, Agarwal N, Makena A, Borthakur S. The Global Landscape of Gender Lens Investing. Mumbai / Ottawa: Intellecap / IDRC; 2019.

63. Roberts PW, Peters S. The Impact of Entrepreneurship Database Program: 2013 YearEnd Data Summary [Internet]. Social Enterprise @ Goizueta; 2014. Available from: http://goizueta.emory.edu/faculty/socialenterprise/documents/2013_End_Summary_Fin al_Final.pdf

64. Post C, Byron K. Women on Boards and Firm Financial Performance: A Meta-Analysis. Acad Manage J. 2015 Oct;58(5):1546-71.

65. Skaggs S, Stainback K, Duncan P. Shaking things up or business as usual? The influence of female corporate executives and board of directors on women's managerial representation. Soc Sci Res. 2012 Jul;41(4):936-48.

66. Eagly $\mathrm{AH}, \mathrm{Carli} \mathrm{LL}$. The female leadership advantage: An evaluation of the evidence. Leadersh Q. 2003 Dec;14(6):807-34.

67. Vecchio RP. Leadership and gender advantage. Leadersh Q. 2002 Dec;13(6):643-71.

68. IFC. The Business Case for Women's Employment in Agribusiness. Washington, DC: International Finance Corporation (IFC); 2017.

69. Miceli AD, Angela Donaggio. Women in Business Leadership Boost ESG Performance: Existing Body of Evidence Makes Compelling Case. Washington, DC: International Finance Corporation (IFC); 2018.

70. Brush CG, Cooper SY. Female entrepreneurship and economic development: An international perspective. Entrep Reg Dev. 2012 Jan;24(1-2):1-6.

71. Ntseane P. Being a female entrepreneur in Botswana: Cultures, values, strategies for success. Gend Dev. 2004 Jul;12(2):37-43.

72. Amine LS, Staub KM. Women entrepreneurs in sub-Saharan Africa: An institutional theory analysis from a social marketing point of view. Entrep Reg Dev. 2009 Mar $1 ; 21(2): 183-211$.

73. IFC. Voices of Women Entrepreneurs in Ghana. Washington, DC: International Finance Corporation (IFC); 2007.

74. Klapper L, Parker S. Gender and the Business Environment for New Firm Creation. World Bank Res Obs. 2011 Aug 1;26(2):237-57.

75. Chinomona E, Maziriri T. Women In Action: Challenges Facing Women Entrepreneurs In The Gauteng Province Of South Africa. Int Bus Econ Res J. 2015;14(6).

76. World Bank. World Bank DataBank [Internet]. 2020 [cited 2020 Jan 6]. Available from: https://data.worlbank.org 
77. ICRW. One Woman = One Business: Why Business and Management Education for Women Is Essential to Economic Development. Washington, DC: International Center for Research on Women (IRW); 2008.

78. World Bank, IFC. Striving for Business Success : Voices of Liberian Women Entrepreneurs. Washington, DC: World Bank \& IFC; 2014.

79. De Groot TU. Women Entrepreneurship Development in Selected African Countries. Vienna: United Nations Industrial Development Organization; 2001. Report No.: Private Sector Development Working Paper 7.

80. Della-Giusta M, Phillips C. Women entrepreneurs in the Gambia: challenges and opportunities. J Int Dev. 2006 Nov;18(8):1051-64.

81. Ellis A, Manuel C, Blackden CM. Gender and Economic Growth in Uganda: Unleashing the Power of Women. Directions in Development. Washington, DC: World Bank; 2005.

82. IFC. SMEs and Women-owned SMEs in Mongolia: Market Research Study. Washington, DC: International Finance Corporation (IFC); 2014.

83. Bowman C, Cutura J, Ellis A, Manuel C. Women in Vanuatu: Analyzing Challenges to Economic Participation. Washington, DC: World Bank; 2009.

84. Aranda-Jan CB, Mohutsiwa-Dibe N, Loukanova S. Systematic review on what works, what does not work and why of implementation of mobile health (mHealth) projects in Africa. BMC Public Health. 2014 Dec;14(1):188.

85. Wyche S, Olson J. Kenyan Women's Rural Realities, Mobile Internet Access, and "Africa Rising." Inf Technol Int Dev. 2018;14:33-47.

86. Demirguc-Kunt A, L Klapper, Singer D, Ansar S, Hess J. The Global Findex Database 2017: Measuring financial inclusion and the fintech revolution. Washington, DC: World Bank; 2018.

87. Muravyev A, Talavera O, Schäfer D. Entrepreneurs' gender and financial constraints: Evidence from international data. Spec Symp Honor Padma Desai. 2009 Jun $1 ; 37(2): 270-86$.

88. Zewde \& Associates. Jobs, Gender and Small Enterprises in Africa: Women Entrepreneurs in Ethiopia. A Preliminary Report. Geneva: International Labour Organization; 2002.

89. McDade BE, Spring A. The 'new generation of African entrepreneurs': networking to change the climate for business and private sector-led development. Entrep Reg Dev. 2005 Jan 17;17(1):17-42.

90. Woldie A, Adersua A. Female entrepreneurs in a transitional economy: Businesswomen in Nigeria. Int J Soc Econ. 2004 Jan;31(1/2):78-93.

91. Nasr S. Egyptian Women Workers and Entrepreneurs: Maximizing Opportunities in the Economic Sphere. Washington, DC: World Bank; 2010.

92. ILO. Tanzanian Women Entrepreneurs: Going for Growth. Geneva: International Labour Organization; 2003. 
93. ANDE. Gender Equality in the SGB Sector. Washington, DC: Aspen Network of Development Entrepreneurs; 2019.

94. CAWTAR. Women Entrepreneurs in the Middle East and North Africa: Characteristics, Contributions and Challenges. Tunis: Center of Arab Women for Training and Research (CAWTAR) adn International Finance Corporation's Gender Entrepreneurship Markets (IFC GEM); 2007.

95. Friedson-Ridenour S, Pierotti RS. Competing priorities: Women's microenterprises and household relationships. World Dev. 2019 Sep;121:53-62.

96. Das M. Women Entrepreneurs from India: Problems, Motivations and Success Factors. J Small Bus Entrep. 2000 Dec;15(4):67-81.

97. Kitching BM, Mishra R, Shu X. Female entrepreneurs in transitional economies: a comparative study of women in the business workplace in India and China. Monash University; 2005. Report No.: 16.

98. APEC. Access to Trade and Growth of Women's SMEs in APEC Developing Economies: Evaluating Business Environments in Malaysia, Philippines, and Thailand. Singapore: Asia-Pacific Economic Cooperation (APEC); 2013 Feb.

99. Roomi MA, Parrott G. Barriers to Development and Progression of Women Entrepreneurs in Pakistan. J Entrep. 2008 May;17(1):59-72.

100. De Vita L, Mari M, Poggesi S. Women entrepreneurs in and from developing countries: Evidences from the literature. Eur Manag J. 2014 Jun 1;32(3):451-60.

101. Ladegaard HJ. 'Doing power' at work: Responding to male and female management styles in a global business corporation. J Pragmat. 2011 Jan;43(1):4-19.

102. Nordhagen S. Integrating Gender Equity into Business Networks for Nutrition. Geneva, Switzerland: Global Alliance for Improved Nutrition (GAIN); 2020. Report No.: GAIN Working Paper 12.

103. World Bank Group. Women, Business and the Law [Internet]. World Bank; 2016. Available from: http://wbl.worldbank.org/ /media/WBG/WBL/Documents/Reports/2016/WBL2016-KeyFindings.pdf

104. World Bank Group. Women, Business and the Law. World Bank; 2020.

105. Tambwe MA. he Impact Of Enterpreneurship Training On Micro And Small Enterprises' (MSES) Performance In Tanzania. Bus Educ J. 2015;1(1).

106. Bruhn M, Zia B. Stimulating managerial capital in emerging markets: the impact of business training for young entrepreneurs. J Dev Eff. 2013 Jun;5(2):232-66.

107. Marshall JN, Alderman N, Wong C, Thwaites A. The Impact of Management Training and Development on Small and Medium-sized Enterprises. Int Small Bus J Res Entrep. 1995 Jul;13(4):73-90.

108. De Mel S, McKenzie D, Woodruff C. Business Training and Female Enterprise Start-up, Growth, and Dynamics: Experimental Evidence from Sri Lanka [Internet]. The World 
Bank; 2012 [cited 2020 Jun 4]. (Policy Research Working Papers). Available from: http://elibrary.worldbank.org/doi/book/10.1596/1813-9450-6145

109. McKenzie D, Woodruff C. What Are We Learning from Business Training and Entrepreneurship Evaluations around the Developing World? World Bank Res Obs. 2014 Feb 1;29(1):48-82.

110. Karlan D, Valdivia M. Teaching Entrepreneurship: Impact of Business Training on Microfinance Clients and Institutions. Rev Econ Stat. 2011 May;93(2):510-27.

111. Ellis A, Kirkwood D, Malhotra D. Economic Opportunities for Women in the East Asia and Pacific Region. Washington, D.C.: World Bank; 2010.

112. Kanze D, Huang L, Conley MA, Higgins ET. We Ask Men to Win and Women Not to Lose: Closing the Gender Gap in Startup Funding. Acad Manage J. 2018 Apr;61(2):586614.

113. ICRW. Catalyzing Growth in the Women-Run Small and Medium Enterprises Sector (SMEs): Evaluating the Goldman Sachs 10,000 Women Initiative. Washington, DC: International Center for Research on Women (IRW); 2012.

114. ILO. Assessing the Enabling Environment for Women in Growth Enterprises, An AfDB/ILO Integrated Framework Assessment Guide. Geneva: International Labour Organization; 2007.

115. Ibeh K, Debrah YA. Female talent development and African business schools. J World Bus. 2011 Jan;46(1):42-9.

116. Mungai EN, Ogot M. Gender, Culture and Entrepreneurship in Kenya. Int Bus Res. 2012 Apr 25;5(5):p175.

117. Mengistae T. Indigenous Ethnicity and Entrepreneurial Success in Africa: Some Evidence from Ethiopia [Internet]. The World Bank; 1999 [cited 2020 Sep 23]. (Policy Research Working Papers). Available from: http://elibrary.worldbank.org/doi/book/10.1596/18139450-2534

118. Agius Vallejo J, Canizales SL. Latino/a professionals as entrepreneurs: how race, class, and gender shape entrepreneurial incorporation. Ethn Racial Stud. 2016 Jul 14;39(9):1637-56.

119. Gender Practitioners Collaborative. Minimum Standards for Mainstreaming Gender Equality. Washington, DC; 2018. 